\title{
CATEGORY OF MODALITY IN ENGLISH AND TATAR PROVERBS: COMPARATIVE ASPECT
}

\author{
Diana I. Khripkova ${ }^{1 *}$, Anna A. Karimova ${ }^{2}$, Oksana V. Khasanova ${ }^{3}$, Elena V. Valeeva ${ }^{4}$ \\ ${ }^{1,2,3}$ Kazan Federal University, Leo Tolstoy Institute of Philology and Intercultural Communication, Russia, \\ ${ }^{4}$ Lobachevsky University of Nizhni Novgorod, Russia. \\ Email: "annushka2812@gmail.com
}

Article History: Received on $12^{\text {th }}$ October 2019, Revised on $29^{\text {th }}$ November 2019, Published on $19^{\text {th }}$ December 2019

\begin{abstract}
Purposes: The article discusses one of the most significant and contradictory categories in linguistics, the category of modality, using the proverbs of two different structural languages like English and Tatar.

Methodology: The basic methods of scientific research are the statistics method, method of comparative and quantities analyses of the data, method of description.

Implications/Applications A systematic study of the complex of multilevel means of expressing the category of modality will help to study the mechanism of action of this category as a functional-semantic subsystem of the language, to determine its essence, volume and boundaries in such different structural languages as English and Tatar.

Results: The results of the study allow us to conclude that the representation of the category of modality is similar in languages of different structures, which may become the basis for assuming the similarity of semantic processes in both languages.

Novelty: The problem of determining modality is still debatable, and research on how to express it in different languages is relevant. The authors give a classification of the selected proverbs; determine the criteria for comparison, on the basis of which determine the general and various ways of expressing modality in folklore texts.
\end{abstract}

Keywords: English, Tatar, modality, proverb, classification.

\section{INTRODUCTION}

Proverbs, created by nation, are an invaluable wealth of any language. Perhaps, no other literary genre reflects people's life as much as a proverb. They may well be called the people's encyclopedia. Each generation accumulated its observations of the world, social and family relationships between people, and these observations, this knowledge is reflected in proverbs. In proverbs, we can find the whole educational experience of a nation, their ethical, social, aesthetic, artistic and educational ideals. They store the history of the development of a nation along the path of civilization; reflect their character, their likes and dislikes, communication with neighboring peoples. Proverbs, omens, riddles absorbed all the details of the assessment relation to reality, its perception and reflection (Kulkova et al., 2015; Boldyrev, 2008; Mubarakshina et al., 2016). One of the main functions of the proverb is the expression of the people's experience to a particular event, phenomenon, behavior, way of thinking, and more. This fact gives the proverb such a category as "modality". Linguistics has come to a long and winding path in the study of modality, based on the achievements of logic, semiotics and psychology (Tarasova et al., 2017; Yusupova et al., 2015; Khrolenko, 1992). However, the modality has not yet been fully explained in connection with its multifaceted nature, the specificity of language expression, and functional features.

One of the first attempts to interpret this term can be found in the linguistic dictionary Zainulli, who defined modality as a conceptual category, representing the expression of the speaker's relationship to what he is saying, as well as the relationship of this message with reality (Zainulli, 1986). The category of modality can be expressed by various lexical and grammatical means, such as form and mood, modal verbs, modal words, etc (Ahmanova, 1966).

V.V. Vinogradov in his work "Studies on Russian Grammar" adhered to the concept that the sentence, reflecting reality in its practical public awareness, expresses relevance (attitude) to reality, therefore the category of modality is closely connected with the sentence, with the diversity of its types. Each sentence includes, as an essential constructive feature, a modal meaning, that is, it contains an indication of the relation to reality. He believed that the category of modality belongs to the main, central linguistic categories, in various forms, found in the languages of different systems. V.V. Vinogradov also noted that the content of the category of modality and the forms of its detection are historically variable. The semantic category of modality in languages of different systems has a mixed lexical and grammatical character. In the languages of the European system, it covers the entire fabric of speech (Vinogradov, 1975).

If in Soviet linguistics the founder of the concept of modality was V.V. Vinogradov, then in West European linguistics this role belongs to S. Balli. According to the Swiss scientist, "modality is the soul of the proposal; like thought, it is formed mainly as a result of the active operation of the speaking subject. Consequently, it is impossible to attach importance to a sentence if a statement is not found in it, at least some expression of modality". The content of the syntactic category of modality in the light of the theory of Sh. Bally combines two meanings, which he, according to the example of logicians, suggests calling: 
1. Dictum (objective content of the sentence);

2. Mode (expression of the position of the thinking subject in relation to this content). "The speaker gives his thoughts either an objective, rational form that corresponds to reality as much as possible, or most often puts emotional elements into expression in the most diverse doses; sometimes the latter reflect the speaker's purely personal motives, and sometimes they change under the influence of social conditions, that is, depending on the real or imaginary presence of some other persons (one or several)" (Bally, 1955).

In Turkology interest in the problems of modality arose long ago, it gained particular popularity in the middle of the last century and took a strong place in modern research.

If you turn to English-language literature with questions about modality, it turns out that they find coverage only in grammar books. British and American grammarians believe that modality is conveyed by auxiliary verbs expressing different types of subjective attitude to an event or action. The values of obligation, possibility, probability, doubt, assumption, request, permission, wishes and others are recognized as modal.

\section{METHODS}

During the study, the theoretical literature on the modality problem was analyzed. As the main provisions were taken work V.V. Vinogradova, B. Chally, G.A. Zolotova, O.S. Akhmanova, R.R. Zamaletdinov, M. Greple, M. Swan, J. Lyons, and others.

To solve the tasks, the following research methods were used:

- Theoretical: generalization and analysis of scientific data on the research problem (from the point of view of linguistics, axiology, psychology, psycholinguistics, cognitive linguistics, etc.);

- Empirical: selection, analysis, and classification of proverbs of the English and Tatar languages obtained by the method of continuous sampling from specialized dictionaries.

\section{RESULTS}

The modality category is differentiated into two types: objective and subjective. Objective modality is an indispensable feature of any utterance, one of the categories forming a predicative unit is a sentence. This type of modality expresses the relation of the communicated to reality in terms of reality (feasibility or feasibility). Objective modality is organically connected with the category of time and is differentiated by the sign of temporal certainty - uncertainty. The meaning of time and reality - irreality merged into one; the complex of these values is called objective-modal values. Subjective modality is the speaker's relation to the message. Unlike objective modality, it is an optional feature of a statement. The semantic volume of subjective modality is much wider than the semantic volume of objective modality. The semantic basis of subjective modality is formed by the concept of evaluation in the broad sense of the word, including not only the logical (intellectual, rational) qualifications of the communicant, but also different types of emotional (irrational) reactions. Valuation and characterizing values include values that combine the expression of a subjective attitude to the message with such a characteristic that may be considered not subjective, arising from the fact itself, the event, from its qualities, properties, from the nature of its course in time or from its connections and relationships with other facts and events.

The modality sphere includes:

- The opposition of statements by the nature of their communicative attitude;

- Gradations of values in the range of "reality - irreality";

- A different degree of confidence of the speaker in the reliability of his thoughts about reality;

- Various modifications of the relationship between subject and predicate.

G.A. Zolotova distinguishes between three main modal plans:

1. The relation of the utterance to reality from the point of view of the speaker;

2. The speaker's attitude to the content of the statement;

3. The relation of the subject of action to action.

At the same time, she explains: "In the works of recent years devoted to questions of modality, the terms objective modality and subjective modality are found" (Zolotova, 1962). Offering to use these very concepts, G.A. Zolotova defines the relationship in the first formulation as objective modality, and in the second is subjective. At the same time, the third modal aspect (the relation between the subject and the action) does not matter for the modal characteristic of the sentence. In our opinion, her conclusions are fair, that:

a) The main modal meaning or objective modality is a necessary constructive sign of each sentence, subjective modality is an optional, optional sign; 
b) Subjective modality, without changing the main modal meaning of the sentence, presents this value in special coverage.

By O.S. Akhmanova gives the following types of modality:

- Hypothetical modality (suppositional modality): presentation of the content of the statement as hypothetical;

- Verbal modality: the modality expressed by the verb;

- Unreal modality: presentation of the content of the statement as impossible, impracticable;

- Negative modality: presentation of the content of the statement as untrue (Akhmanova, 2007).

In most English grammar information was found only on modal verbs and their semantics. Swan, in particular, pointed out that modality in grammar (English) was considered to be in the form of values such as will (volatility) and possibility or necessity. He also added that verbs expressing these values were called "modal auxiliary verbs" (Close, 1979; Swan, 1984; Khripkova et al., 2018).

Thus, criteria and grounds were identified for the classification of English and Tatar proverbs, as well as for highlighting the lexical and grammatical means of expressing modality.

\section{SUMMARY}

Summing up the results of a comprehensive analysis of the proverbs of English and Tatar languages containing a modal plan, we can draw the following conclusions:

1. The question of the expression of modality has always been and remains in the focus of attention of such branches of linguistics as semasiology and functional lexicology, which consider the word as the main unit of language in all its diversity. The category of modality is significant in English and Tatar, regardless of the difference in the structures of these languages;

2. Based on the analysis of practical material, funds and methods for expressing modal relationships in the Tatar language were allocated, which were integrated into 3 groups. The first group consists of words that enter the predicate fabric. These include suffixes that simultaneously express predictivity, i.e. personal suffixes, mood suffixes, and time suffixes. Included here are auxiliary words, which are usually used in the predicate. For example, bulsa kirek "seems", bugay "apparently", tiyesh "should", etc. The second group includes particles, interrogative pronouns in the role of particles, interjections, word order and intonation. The third group includes special sentence members, usually called introductory words, introductory sentences, and references.

3. The main ways of expressing modality in English proverbs include modal verbs (can (could), may (might), must, should, shall, ought to, need, will (would)) and modal words, which can be divided into 4 groups:

a) Modal words expressing doubt and assumption, uncertainty about the reliability of the message: maybe, perhaps, probably;

b) Modal words expressing approval or disapproval: fortunately, unfortunately, luckily, unluckily, happily, unhappily;

c) Modal words expressing amplification: really;

d) Modal words expressing confidence, reliability of the message: course, sure, sure, to be sure, sure enough, evidently, obviously, no doubt, naturally.

4. Within each group, modal words are close in meaning, but at the same time, each of them expresses its own shades or differs in its use in the speech from other modal words of the same semantic group.

\section{CONCLUSIONS}

So, modality is a category that expresses the speaker's attitude to the content of the statement, the latter's attitude to reality. Since modality is a multidimensional phenomenon, various opinions and arguments are expressed in linguistic literature. To the sphere of modality include the opposition of statements by the nature of their communicative attitude; gradations of values in the range of "reality - irreality"; different degrees of confidence of the speaker in the reliability of his thoughts about reality. Thus, modality can be realized at the grammatical, lexical and intonational level and have various ways of expression; it is expressed by various grammatical and lexical means: modal verbs, words, forms of moods.

During the research we selected and classified 112 proverbs, English - 69 and 43 Tatar, expressing any modality. Quantitative results were listed in table 1.

Table 1: Comparative analysis of the frequency of expression of types of modality in English and Tatar proverbs

\begin{tabular}{ccc}
\hline Types of Modality & $\begin{array}{c}\text { Presence of Modality in English } \\
\text { Proverbs }\end{array}$ & $\begin{array}{c}\text { Presence of Modality in Tatar } \\
\text { Proverbs }\end{array}$ \\
\hline
\end{tabular}




\begin{tabular}{ccc}
\hline $\begin{array}{c}\text { Hypotheticalmodality } \\
\text { (suppositional modality) }\end{array}$ & Rarely used (8) & Rarely used (4) \\
\hline Verbal modality & Often used (49) & Rarely used (6) \\
\hline Unreal modality & Sometimes used (18) & Sometimes used (12) \\
\hline Negative modality & Often used (43) & Do not use (0) \\
\hline
\end{tabular}

It can be seen from the table that English proverbs express the modal component much more often than Tatar proverbs, which makes the statement more emotional. The Tatar language often resorts to grammatical means of expressing modality, English to lexical ones. This can be explained by the difference in the structures of the languages studied. In English, you can find all kinds of modal relationships in accordance with the classification described, in the Tatar language there is no negative modality, which suggests a lack of categorization in folklore texts.

\section{ACKNOWLEDGMENTS}

The work is performed according to the Russian Government Program of Competitive Growth of Kazan Federal University.

\section{REFERENCES}

1. Kulkova, M. A., Fattakhova, N. N., \& Zinecker, T. (2015). Paremiological text hermeneutics (in Russian and German). Journal of Language and Literature, 6(2), 356-360.

2. Boldyrev, N. N. (2008). Assessment categories as a new form of knowing, Cognitive language exploring. Tambov, 3, 25-37.

3. Mubarakshina, A., Fattahova, N., \& Fedorova, N. (2016). Associative-semantic field of" nravstvennost" in modern Russian language. Journal of Language and Literature, 280-284.

4. Tarasova, A. O., Gizatullina, A. K., Mingazova, R. R., \& Brussoix, G. (2017). Emotional And Expressive Sentences In Tatar And French: Representation As A Semantic Component Of Expressivity. Modern Journal of Language Teaching Methods, 7(11), 171-176.

5. Yusupova, A. S., Mugtasimova, G. R., Nabiullina, G. A., \& Denmukhametova, E. N. (2015). Proverbs of the Tatar People as Part of Ethnic Identity. Mediterranean Journal of Social Sciences, 6(6 S2), 161. https://doi.org/10.5901/mjss.2015.v6n6s2p161

6. Khrolenko A. T. (1992). Folk word's semantics. 70-71.

7. Zainulli, M. V. (1986). Modality as a functionally semantic category. On the material of the Bashk. Language. Saratov University Press: Saratov.

8. Ahmanova, O. S. (1966). Dictionary of linguistic terms. Publishing House Soviet Encyclopedia: Moscow.

9. Vinogradov, V. V. (1975). On the category of modality and modal words in the Russian language. Izbrannye trudy. Issledovaniya po russkoi grammatike, 53-87.

10. Bally, S. (1955). General Linguistics and French Issues. - M .: Publishing house of foreign literature, $416 \mathrm{p}$.

11. Zolotova, G. A. (1962). On the modality of sentences in Russian. Philological Sciences, 4, 65-79.

12. Akhmanova, O. S. (2007). Dictionary of linguistic terms. ed. 4th erased - M.: Kom Kniga, 576 p.

13. Close, R. A. (1979). A reference grammar for students of English. M, Prosveshcheniye: 352.

14. Swan, M. (1984). Practical English usage. M, high school. 552.

15. Khripkova, D. I., Khasanova, O. V., Karimova, A. A., \& Valeeva, E. V. (2018). A Research into Modality in English, Spanish, and Tatar Proverbs. The Journal of Social Sciences Research, 1,208-212.

16. Kajumova, D., Sadykova, A., Aleeva, G., Zakirova, L., Vildanova, E., Tyalleva, I., ... \& Khripkova, D. (2018). INVESTIGATING THE MODALITY IN ENGLISH, SPANISH AND TATAR PROVERBS. National Academy of Managerial Staff of Culture and Arts Herald, (3).

17. Abrosimova, G., Galiullina, E., Voronina, E., Kondrateva, I., Madyakina, N., Mukhametshina, E., \& Khabirova, N. (2018). Incentive Modality in Tatar and English Languages. International Information Institute (Tokyo). Information, 21(5), 1563-1571.

18. Khabirova, N., Abrosimova, G., Minullin, K. M., Khanipova, I., Khairutdinov, R. R., \& Ibragimov, G. (2017). Means of expression of incentive modality in Tatar and English languages. Journal of Fundamental and Applied Sciences, 9(7S), 1193-1203.

19. Giniyatullina, A. Y., Garaeva, M. R., Bushkanets, L. E., Timerhanov, A. A., Khanipova, I., Khairutdinov, R. R., \& Ibragimov, G. (2017). Morphological and syntactical features of adjectives in English and Tatar participles. Journal of Fundamental and Applied Sciences, 9(7S), 1277-1285.

20. Abish, A. (2014). Modality in Kazakh as spoken in China (Doctoral dissertation, Uppsala University, Department of Linguistics and Philology). 